AperTO - Archivio Istituzionale Open Access dell'Università di Torino

\title{
Moniliformin Analysis in Maize Samples from North-West Italy Using Multifunctional Clean-up Columns and the LC-MS/MS Detection Method.
}

\section{This is the author's manuscript}

Original Citation:

Availability:

This version is available http://hdl.handle.net/2318/136210

since 2016-07-04T19:35:45Z

Published version:

DOI:10.1080/19440049.2013.793825

Terms of use:

Open Access

Anyone can freely access the full text of works made available as "Open Access". Works made available under a Creative Commons license can be used according to the terms and conditions of said license. Use of all other works requires consent of the right holder (author or publisher) if not exempted from copyright protection by the applicable law. 


\section{(2) \\ UNIVERSITÀ DEGLI STUDI DI TORINO}

This is an author version of the contribution published on:

Questa è la versione dell'autore dell'opera:

[Food Additives and Contaminants, Part A, 30:5, 2013, pag. 876-

884, DOI: 10.1080/19440049.2013.793825.

The definitive version is available at:

La versione definitiva è disponibile alla URL:

[http://www.tandfonline.com/toc/tfac20/current\#.U7VUF_I_ugY] 
FOOD ADDITIVES \& CONTAMINANTS: PART A, 2013 - 30:5, 876-884, DOI: 10.1080/19440049.2013.793825.

Moniliformin Analysis in Maize Samples from North-West Italy

Using Multifunctional Clean-up Columns and the LC-MS/MS

Detection Method

Authors:

Valentina Scarpino, Massimo Blandino*, Michele Negre, Amedeo Reyneri, Francesca Vanara

Affiliation:

Università di Torino, Dipartimento di Scienze Agrarie, Forestali e Alimentari, via Leonardo Da Vinci 44, 10095 Grugliasco (TO), Italy.

* Corresponding author: Tel: +39-011-6708895; fax +39-011-6708798.

E-mail address: massimo.blandino@unito.it

\section{ACKNOWLEDGEMENTS}

The research has been conducted thanks to the financial support of the Italianl Ministry of Agricultural, Food and Forestry Policies (MIPAAF), as a part of the MICOPRINCEM project (Coordinator Dr. Maria Grazia D’Egidio, CRA QCE). 
ABSTRACT: A fast clean-up method has been developed to purify maize extracts and to detect moniliformin (MON) in maize samples from North-West Italy over a four-year period (2008-2011). The method is based on the use of MycoSep ${ }^{\circledR} 240$ Mon clean-up columns (Romer Labs ${ }^{\circledR}$ ). Samples were extracted using acetonitrile/water $(84: 16, \mathrm{v} / \mathrm{v})$, and the extracts were purified in the previously described clean-up columns. The LC-MS/MS analysis has been carried out by means of hydrophilic interaction chromatography (HILIC), combined with negative electrospray mass spectrometry (ESI - MS). The developed method has a recovery rate of 76-91\% (RSD\%: 6-14\%), a limit of detection (LOD) of $1 \mu \mathrm{g} \mathrm{kg}$, and a limit of quantification (LOQ) of $4 \mu \mathrm{g} \mathrm{kg}^{-1}$. One hundred and eight different naturally contaminated maize samples were analyzed for their MON content. The average percentages of positive samples was $93 \%$ with the following ranges $(\mu \mathrm{g}$ $\mathrm{kg}^{-1}$ ): 33-2606 (2008); < LOD-527 (2009); < LOD-920 (2010); < LOD-409 (2011).

KEYWORDS: Moniliformin, maize, mycosep clean-up columns, LC-MS/MS, Fusarium 


\section{ABBREVIATIONS}

2 EFSA, European Food Safety Authority; ESI, electrospray ionization; GDD

3 Accumulated growing degree days; HILIC, hydrophilic interaction

4 chromatography; HPLC, high-performance liquid chromatography; LOD, limit of

5 detection; LOQ, limit of quantification; MON, moniliformin; MS, mass

6 spectrometry detection; RSD, relative standard deviation; SAX, strong ion

7 exchange; SPE, solid phase extraction.

8

\section{INTRODUCTION}

Moniliformin (MON) is a worldwide Fusarium mycotoxin which often occurs in cereals and maize (Sharman et al. 1991). MON is a small $\left(98.0081 \mathrm{~g} \mathrm{~mol}^{-1}\right)($ Betina 1989), highly polar, acidic molecule. Due to the low $\mathrm{pK}_{\mathrm{a}}$ value $(<1.7)$ of the free acid (semisquaric acid), MON does not occur as an acid in nature but as a water soluble sodium or potassium salt (Steyn et al. 1978).

It was first isolated by Cole et al. in 1973 (Cole et al. 1973) and structurally characterized as the sodium or potassium salt of 1-hydroxycyclobut-1-ene-3,4dione (Figure 1) by Springer et al. in 1974 (Springer et al. 1974). MON can produce plant growth regulation and phytotoxic effects in plant systems (Cole et al. 1973, Vesonder et al. 1992). MON is also toxic to several animal species, causing myocardial changes, muscular weakness, respiratory distress, cyanosis, coma, and death (Kriek et al. 1977). The action mechanism probably involves selective 
inhibition of the pyruvate and $\alpha$-ketoglutarate dehydrogenase enzyme systems (Burka et al. 1982). MON toxicity mainly affects cockerels $\left(\mathrm{LD}_{50}=4.00 \mathrm{mg} \mathrm{kg}^{-1}\right.$, oral) and ducklings $\left(\mathrm{LD}_{50}=3.68 \mathrm{mg} \mathrm{kg}^{-1}\right.$, oral) (Kriek et al. 1977).

MON is produced by several Fusarium species on several crops, and has been found in different geographical areas. The main Fusarium species that are able to produce MON are listed in Table 1. MON contamination is higher in maize than in other substrates and, in South Europe, it is commonly produced in maize infected by F. proliferatum and F. subglutinans. Both species can be found globally, but the optimum temperature for growth of $F$. subglutinans is lower than that of $F$. proliferatum, thus the former is more common in temperate areas (Kostecki et al. 1999). In a study of the incidence, geographic distribution and toxigenicity of Fusarium species in South African maize, F. subglutinans was found to predominate in relatively cool and humid climates (Rabie et al. 1982). Since 1982, when it was first reported as a natural contaminant in Transkeian maize (16-25 mg $\mathrm{kg}^{-1}$ ) (Thiel et al. 1982), MON has been found in maize in different parts of the world. This mycotoxin was detected in maize ears in Poland, from 1985 to 1991, and the average content over these six years was $131 \mathrm{mg} \mathrm{kg}^{-1}$ (Chelkowski et al. 1987, Chelkowski 1989, Lew et al. 1996). It has also been found to occur in Austrian maize, with levels of up to $20 \mathrm{mg} \mathrm{kg}^{-1}$ (Lew et al. 1991), as well as in Canada, Germany, and New Zealand (Lamprecht et al. 1986, Scott et al. 1987, Thalman et al. 1985). In these surveys the original samples were hand-selected in order to collect visibly Fusarium infected kernels, thus high levels of MON 
contamination were reported. Instead, the results of surveys on MON concentrations and distribution in naturally contaminated maize grain from field or commercial lots, which are reported in Table 2, have shown lower levels of MON concentration.

Several approaches have been developed for the selective extraction, sample purification, chromatographic separation and detection of MON.

Liquid Chromatography has been the main chromatographic technique used in the analysis of MON and due to the highly polar properties of this mycotoxin the most common procedure used in the years was the application of ion-pairing mobile phases to achieve a good chromatographic separation with reversed-phase columns (Shepherd and Gilbert 1986, Munimbazi and Bullerman 1998, Sewram et al. 1999). More recent approaches to improve the chromatographic separation were the use of hydrophilic interaction chromatography (HILIC) (Sørensen et al. 2007) and the Gemini C6-Phenyl column as reversed-phase column (Von Bargen et al. 2012).

Until now, the several analytical methods that have been reported in literature have used commercial SPE-columns for the purification of MON extracts. These mainly have been strong anion exchanger (SAX) columns (Munimbazi and Bullerman 1998, Filek and Lindern 1996, Parich et al. 2003, Sørensen et al. 2007, Von Bargen et al. 2012), but also nonpolar $\mathrm{C}_{18}$-columns (Shepherd and Gilbert 1986), or a combination of the two (Sharman et al. 1991). However, Jestoi et al. (Jestoi et al. 
2003) did not apply any sample purification steps, except filtering and concentration, in order to reduce the loss of MON during the analysis.

Since these purification methods are time consuming and require several steps, they could lead to analytical errors and a detriment of analytical repeatability. In addition, not applying a purification step can lead to the instrumentation becoming dirty, thus impairing the analysis.

The purpose of the current study was to develop a fast, reliable and repeatable clean-up method, using MycoSep ${ }^{\circledR} 240$ Mon clean-up columns (Romer Labs ${ }^{\circledR}$ ) for the first time to purify maize extracts prior to the analytical determination of MON. Moreover the European Food Safety Authority (EFSA) is currently working on establishing a scientific opinion on the risks to public health related to the presence of MON in feeds and food (EFSA 2010). Since there is this need to obtain major information about the incidence of this mycotoxin in the most important cereal areas in the EU, this procedure has been applied to maize samples collected over a four-year period (2008-2011) in North-West Italy in order to obtain data about the presence, diffusion and level of MON contamination. A first attempt has been made to individuate the conditions which could lead to a higher contamination of this mycotoxin. 


\section{MATERIALS AND METHODS}

\section{Chemicals}

All the chemicals and analytical standards were purchased from Sigma Aldrich (St. Louis, MO), or VWR (Milan, Italy). The solvents were gradient grade or LC-MS grade.

The MON standard was purchased as sodium salt and a $93 \mathrm{mg} \mathrm{L}^{-1}$ stock solution of MON in acetonitrile/water $(84: 16, \mathrm{v} / \mathrm{v})$ was prepared and stored at $4{ }^{\circ} \mathrm{C}$. This stock solution was used to prepare standard solutions through dilution with acetonitrile/water $(84: 16, \mathrm{v} / \mathrm{v})$.

\section{Samples}

One hundred and eight maize grain samples, collected over 4 years in farm fields in North-West Italy (Torino and the Cuneo Province), were analyzed for natural MON contamination. The number of maize grain samples collected each year was 16,16 , 40 and 36 in 2008, 2009, 2010 and 2011, respectively. The fields were cultivated under irrigation with full length maturity hybrids, planted in each growing season in the period between the last decade of March and the first decade of April. The normal agronomic techniques of each area were adopted. The considered fields were characterized by a natural infestation of European Maize Borer (ECB, Ostrinia nubilalis Hübner) each year and in each site, since no insecticide was applied to control ECB or other insects during the ripening period. 
106 One hundred ears (included the ears used for the evaluation of ECB incidence and 107 severity at harvest) were collected by hand for each maize kernel sample in each 108 field at the end of maturity (moisture content of grains of between 23 and 27\%) 109 from five subplots and shelled using an electric sheller. The kernels from each plot 110 were mixed thoroughly to obtain a random distribution; $5 \mathrm{~kg}$ samples were then 111 taken to analyze the MON content and dried at $50^{\circ} \mathrm{C}$ for 3 days.

112 ECB damage incidence was calculated as the percentage of ears per plot with 113 kernel injuries or apical and basal tunnels in the cob due to larvae activity. The 114 ECB damage severity was calculated as the percentage of kernels per ear with 115 injuries due to larvae activity. A scale of 1 to 7 was used in which each numerical 116 value corresponded to a percentage interval of surfaces exhibiting visible kernel 117 damage due to larvae activity according to the following schedule: $1=$ no injuries, $1182=1-5 \%, 3=6-10 \% ; 4=11-20 \%, 5=21-35 \%, 6=35-60 \%, 7>60 \%$ (Blandino 119 et al. 2009). The ECB damage severity scores were converted to percentages of 120 ears exhibiting symptoms and each score was replaced with the mid-point of the 121 interval. 


\section{Chemical Analyses}

\section{Sample Preparation and Extraction}

Maize samples were ground using a ZM 200 Ultra Centrifugal Mill (Retsch GmbH, Haan, Germany) and the flour was used directly for the extraction. Twenty five $g$ ground maize samples from a MON-free sample were spiked in order to evaluate the recovery rate of the analytical method. Three replicas with $100 \mu \mathrm{L}$ of pure solvent, or $0.93 ; 9.3 ; 93 \mathrm{mg} \mathrm{MON} \mathrm{L}^{-1}$; or $1000 \mu \mathrm{L}$ of $93 \mathrm{mg} \mathrm{MON} \mathrm{L}^{-1}$ were used to obtain spiked MON levels of $0,3.72,37.2,372$, and $3720 \mu \mathrm{g} \mathrm{kg}^{-1}$ for LC-MS/MS determination. The experiments were performed on four different days to establish day to day variations. The spiked maize samples were incubated at room temperature $2 \mathrm{~h}$ prior to extraction, which allowed the solvent to evaporate and MON to enter the material.

Twenty five g maize flour was extracted by mechanical shaking at $100 \mathrm{rpm}$ for $1 \mathrm{~h}$ (shaker mod. M102-OS, MPM Instruments, Milan, Italy) with $100 \mathrm{~mL}$ acetonitrile/water $(84: 16, \mathrm{v} / \mathrm{v})$. The extracts were filtered through Whatman no. 1 filters (Brentford, UK) and subjected to clean-up and purification.

\section{Clean-up}

Two clean-up methods were tested. The first method was performed with Strata SAX (Strong Anion Exchange) columns (500 mg) (Phenomenex, Torrance, CA) applying the clean-up procedure described by Sørensen et al. (Sørensen et al. 
150

151

152

157 from the Romer Labs ${ }^{\circledR}$ procedure. The cleanup MycoSep ${ }^{\circledR}$ columns were pushed 158 into test tubes containing $5 \mathrm{~mL}$ of the sample extracts, forcing the extracts to filter 159 upwards through the packing material of the columns. The interferences adhered to 160 the chemical packing in the columns and the purified extracts, containing MON, 161 passed through the columns. The evaporation to dryness under nitrogen step was 162 excluded because it provoked a loss of MON of up to $40 \%$. The use of silanized 163 vials, which were adopted to avoid the adsorption of MON on the glass, did not 164 improve the recovery. The purified extracts $(1.5 \mathrm{~mL})$ were transferred to HPLC 165 vials and analyzed by means of LC-MS/MS according to the method described 166 below.

167 This one step cleanup required less than one minute per sample, while the method 168 based on SAX clean-up, because of the long time required to evaporate the $\mathrm{HCl}$ 169 aqueous solution, was much more time consuming. 


\section{$L C-M S / M S$}

173 LC-MS/MS analysis was carried out on a Varian 310 triple quadrupole mass

174

175 176

187 Calibration

188 Ten different MON concentrations were prepared for calibration in 189 acetonitrile/water $(84: 16, \mathrm{v} / \mathrm{v})$, between 0.93 and $930 \mu \mathrm{g} \mathrm{L}^{-1}$. A linear regression 190 was used to obtain the regression curve. spectrometer (Varian, Italy) equipped with an electrospray ionization ESI source, a 212 LC pump, a ProStar 410 AutoSampler and dedicated software. LC separation was performed on a $100 \mathrm{~mm} \times 2.1 \mathrm{~mm}$ i.d., $3.5 \mu \mathrm{m}, 100 \AA$ ZIC ${ }^{\circledR}$-HILIC (Merck, SeQuant, Milan, Italy) column. The mobile phase consisted of water buffered with $100 \mathrm{mM}$ ammonium formate ( $\mathrm{pH}$ 6.4) (A) and acetonitrile (B) delivered at 200 $\mu \mathrm{L} / \mathrm{min}$. The gradient was 5 to $50 \% \mathrm{~A}$ in $7 \mathrm{~min}$. Mass spectrometric analyses were performed in the negative -ion mode. The nebulising gas was $\mathrm{N}_{2}(20 \mathrm{psi})$, the drying gas was air $\left(250{ }^{\circ} \mathrm{C}, 25 \mathrm{psi}\right)$, the needle voltage was $-3000 \mathrm{~V}$, the shield voltage was $-600 \mathrm{~V}$, the detector voltage was $1250 \mathrm{~V}$, the capillary voltage was -20 $\mathrm{V}$ and the collision energy voltage was $12 \mathrm{~V}$. The deprotonated molecule $(\mathrm{m} / \mathrm{z}=$ 97.0) was fragmented to its product ion $(m / z=41.0)$ and used for quantification and identification purposes. 


\section{LC-MS/MS Analyses}

195 Previous studies on the chromatographic separation of MON reported the use of 196 different types of columns. The chromatography of the current study was based on 197 the Sørensen et al. (Sørensen et al. 2007) method and the authors own observations 198 during the development of the LC-MS/MS method. The MON retention time with 199 the HILIC gradient program was 3.9 min with a runtime of $17 \mathrm{~min}$ (Figure 2). This runtime was necessary to elute, with $50 \%$ water buffered with $100 \mathrm{mM}$ ammonium formate, stronger retained contaminant compounds than MON. MON is a strong acid and hence produces more negative than positive ions. Negative ion polarity usually generates less background noise than the positive mode, therefore improving sensitivity. ESI was therefore adopted, in negative mode, in the current study using a triple-quadrupole instrument. The presumed MON fragmentation pathway is shown in Figure 3. Unfortunately, in tandem mass spectrometers MON generates only one strong product ion in the collision cell of the instrument. Thus, only one MRM, the fragmentation of $\mathrm{m} / \mathrm{z} 97$ to $\mathrm{m} / \mathrm{z} 41$ can be programmed (Jestoi et al. 2003). To improve the sensitivity and specificity of the analysis of MON and to avoid the use of the only possible transition in tandem mass spectrometry, a recent approach was the use of a high resolution instrument (Von Bargen et al. 2012). 
215 Several surveys have shown the columns most frequently adopted for SPE clean up procedures, to purify maize and cereal grain extracts, are SAX columns (Sharman et al. 1991, Munimbazi and Bullerman 1998, Filek and Lindner 1996, Sørensen et al. 2007). When these clean-up procedures were applied to ours samples, low 219 recoveries were observed $(\leq 50 \%)$, with one working day being necessary for five samples. The MycoSep ${ }^{\circledR}$ column clean-up was instead much less time consuming

221 (less than 1 min per sample) and the matrix effect was reduced. This phenomenon, 222 known as suppression, is caused by the co-eluting matrix components, which 223 interfere with the ionization of the analyte (Tang and Kebarle 1993, Gilar et al. 224 2001).

225 When the whole Romer Labs ${ }^{\circledR}$ procedure was applied low recoveries were 226 obtained. For this reason it was hypothesised that the concentration step by 227 evaporation to dryness under nitrogen could be a significant factor in the loss of 228 MON, even when silanized vials were used. Higher recoveries were obtained by 229 excluding this concentration step from the Romer Labs ${ }^{\circledR}$ procedure.

230 Thus, because of the higher recoveries and reduced time necessary, MycoSep ${ }^{\circledR}$ 231 columns were used and the previously described clean-up procedure was applied to 232 purify maize samples.

233 The percentage of recovery (Table 3) ranged from 76 to $91 \%$ (Relative Standard 234 Deviation, RSD\%: 6-14\%), independently of the MON concentration. 
235 No differences were observed in recovery rate between the three days, thus 236 confirming the repeatability of the method.

237 The limit of detection (LOD) and the limit of quantification (LOQ) were $1 \mu \mathrm{g} \mathrm{kg}^{-1}$ 238 and $4 \mu \mathrm{g} \mathrm{kg}^{-1}$, respectively.

239 The results attest the accuracy, repeatability and robustness of the method, which 240 has here been applied to maize extracts for the first time.

\section{Naturally Contaminated Samples}

243 The developed analytical method was applied to 108 maize samples collected over 244 a four-year period (2008-2011) in North-West Italy, in order to obtain data about 245 the presence, diffusion and level of contamination of MON in the grain maize 246 cultivated in this area.

247 The considered growing seasons showed remarkably different meteorological 248 trends (Table 4). The years 2008 and 2010 were characterized by low growing 249 degree days (GDDs) and high rainfall, in particular during the 2010 growing 250 season, from the early milk stage to the harvest. The year 2009 had ordinary GDDs 251 and rainfall from flowering to the end of ripening. The year 2011 was instead 252 characterized by high GDDs and extremely limited rainfall from the milk stage to 253 the harvest.

254 Table 5 summarized the percentages of positives samples, the arithmetic mean $( \pm$ 255 RSD) and the range of MON contamination for each sampling year. Overall, the average percentages of positive samples was $93 \%$, with the following ranges $(\mu \mathrm{g}$ 
$\mathrm{kg}^{-1}$ ): 33-2606 (2008); < LOD-527 (2009); < LOD-920 (2010); < LOD-409 (2011).

The MON concentration means $\left(\mu \mathrm{g} \mathrm{kg}^{-1}\right)( \pm$ standard deviation) for each year were: $1127 \pm 784$ (2008); $106 \pm 135$ (2009); $262 \pm 243$ (2010); $89 \pm 99$ (2011).

On the basis of the results of the MON contamination it is possible to state that this mycotoxin is diffused through the investigated areas and shows considerably high levels for each sampling year. However, considering that there is a lack of MON contamination diffusion data in literature and a lack of recent data performing to the most important cereal areas in the EU, it has not been possible to conduct an exhaustive comparison. Nevertheless, on the basis of Table 2 it can be seen that ours results are in agreement with the worldwide levels of MON contamination present in naturally contaminated maize commodities.

Table 6 summarized the mean data of ECB incidence and severity of ears collected for each sampling year. The samples collected in the year 2008 showed the highest ECB severity, and thus was followed by those harvested in 2010. The ECB pressure was lower in 2009 and 2011.

The collected data confirm an important link between MON contamination and ECB activity performing to the damage of maize ears, which was also observed also by Papst et al. (Papst et al. 2005) in Germany, in a comparative study on Bt maize and its isogenic counterparts. Moreover, Papst et al. (Papst et al. 2005) and Magg et al. (Magg et al. 2003) reported a significant correlation between the percentage of ECB damaged ears and the MON concentration in the kernel: the 
MON content in ears manually infested with ECB larvae was 3 times higher than the control, which has been protected through an insecticide application. In temperate areas, F. verticillioides is favoured more by ECB larvae feeding than other Fusarium species (Lew et al. 1991). In the years with high rainfall and low temperatures, the development of F. verticillioides on damaged areas of kernels, caused by second generation ECB, could be less predominant than other fungi, such as $F$. subglutinans and $F$. proliferatum, which commonly cause MON contamination. On the basis of these assumptions, and the different meteorological trends of the considered growing seasons (Table 4), the mean MON concentration data collected for each year could explain why 2008 and 2010 had the highest MON contamination.

In conclusion, the obtained results indicate that the developed clean-up procedure, which was here used for the first time, is very fast, highly accurate, repeatable and robust. Since this method allows a reliable quantification of MON in maize samples as low as $4 \mu \mathrm{g} \mathrm{kg}^{-1}$, it was possible to quantify MON in more than $90 \%$ of the analyzed samples. Moreover, the present work provides a first important series of data on natural MON contamination in maize kernels, referring to several growing seasons with different meteorological trends. The first collected data suggest that the risk of MON contamination in the North Italian cropping area increases for growing seasons with higher rainfall and lower temperatures, from the early milk stage to the harvest. Furthermore, an important link exists between MON contamination in kernels and injuries caused by ECB larvae on maize ears. 
300 The first MON results obtained in the current study could be very useful for EFSA

301 in order to assess the risks to human and animal health related to this mycotoxin.

302 These data need to be integrated with information from maize, other cereal grains

303 and derived products from the main cropping areas. Thus, the new clean-up 304 procedure could be utilized to quantify MON occurrence in an accurate but rapid 305 and efficient way.

306

307

308 


\section{REFERENCES}

Adler, A.; Lew, H.; Brodacz, W.; Edinger, W.; Oberforster, M. 1995. Occurrence of moniliformin, deoxynivalenol and zearalenone in durum wheat (Triticum durum Desf.). Mycotoxin Research. 11:9-15.

Betina, V. 1989. Mycotoxins - chemical, biological and environmental aspects. In Bioactive molecules; Elsevier Science Publishers: Amsterdam, The Netherlands. Vol. no. 9, pp. 438.

Blandino, M.; Reyneri, A.; Vanara, F.; Pascale, M.; Haidukowski, M.; Campagna, C. 2009. Management of fumonisin contamination in maize kernels through the timing of insecticide application against European maize borer. Food Addit. Contam. 26(11):1501-1514.

Burka, L. T.; Doran, J.; Wilson, B. J. 1982. Enzyme inhibition and the toxic action of moniliformin and other vinylogous $\alpha$-ketoacids. Biochem. Pharmacol. $31: 79-84$.

CFP/EFSA/CONTAM/2008/01. Scientific information on mycotoxins and natural plant toxicants. Accepted for Publication on 23 November 2009. Prepared by Battilani, P.; Costa, L. G.; Dossena, A.; Gullino, M. L.; Marchelli, R.; Galaverna, G.; Pietri, A.; Dall'Asta, C.; Giorni, P.; Spadaro, D.; Gualla, A. 
Chelkowski, J. 1989. Mycotoxins associated with maize cob fusariosis. In: Chelkowski, J. (ed.), Fusarium-Mycotoxins, Taxonomy, and Pathogenicity. Elsevier, Amsterdam. 53-62.

Chelkowski, J.; Zajkowki, P.; Zawadzki, M.; Perkowski J. 1987. Moniliformin, deoxynivalenol, 3acetyldeoxynivalenol and zearalenone - Mycotoxins associated with maize cob fusariosis in Poland. Mycotoxin Research special issue. 25-27.

Cole, R. J.; Kirksey, J. W.; Cutler, H. G.; Doupnik, B. L.; Peckham, J. C. 1973. Toxin from Fusarium moniliforme - effects on plants and animals. Science. 179:1324-1326.

EFSA Request for a scientific opinion on the risks for public health related to the presence of moniliformin in feed and food, Mandate M-2010-0312, Reception Date 21-07-2010, Acception Date 09-09-2010.

Filek, G.; Lindner, W. 1996. Determination of the mycotoxin moniliformin in cereals by high-performance liquid chromatography and fluorescence detection. J. Chromatogr., A 732:291-298.

Gilar, M.; Bouvier, E. S. P.; Compton, B. J. 2001. Advances in sample preparation in electromigration, chromatographic and mass spectrometric separation methods. J. Chromatogr., A 909:111-135.

Gutema, T.; Munimbazi, C.; Bullerman, L. B. 2000. Occurrence of fumonisins and moniliformin in maize and maize based food products of U.S. origin. J. Food Prot. 63:1732-1737. 
Jestoi, M.; Rokka, M.; Rizzo, A.; Peltonen, K.; Parikka, P.; Yli-Mattila, T. 2003. Moniliformin in Finnish grains: Analysis with LC-MS/MS. Aspects Appl. Biol. 68:211-216.

Jestoi, M.; Rokka, M.; Yli-Mattila, T.; Parikka, P.; Rizzo, A.; Peltonen, K. 2004. Presence and concentrations of the Fusarium-related mycotoxins beauvericin, enniatins, and moniliformin in Finnish grain samples. Food Addit. Contam. 21(8):794-802.

Kostecki, M.; Wisniewska, H.; Perrone, G.; Ritieni, A.; Golinski, P.; Chelkowski, J.; Logrieco, A. 1999. The effects of cereal substrate and temperature on production of beauvericin, moniliformin and fusaproliferin by Fusarium subglutinans ITEM-1434. Food Addit. Contam. 16:361-365.

Kriek, N. P.; Marasas, W. F. O.; Steyn, P. S.; van Rensburg, S. J.; Steyn, M. 1977. Toxicity of a moniliformin-producing strain of Fusarium moniliforme var. subglutinans isolated from maize. Food Cosmet. Toxicol. 15:579-587.

Krysinska-Traczyk, W.; Kiecana, I.; Perkowski, J.; Dutkiewicz, J. 2001. Levels of fungi and mycotoxins in samples of grain and grain dust collected on farms in Eastern Poland. Ann. Agr. Env. Med. 8(2): 269-274.

Lamprecht, S. C.; Marasas, W. F. O.; Thiel, P. G.; Schneider, D. J.; Knox-Davies, P. S. 1986. Incidence an toxigenicity of seedborne Fusarium species from Annual Medicago species in South Africa. Phytopathology. 76:1040-1041.

Leslie, J. F.; Marasas, W. F. O.; Shephard, G. S.; Sydenham, E. W.; Stockenström, S.; Thiel, P. G. 1996. Duckling toxicity and production of fumonisin and 
moniliformin by isolates in the A and F mating population of Gibberella fujikuroi (Fusarium moniliforme). Appl. Environ. Microbiol. 62:1182-1187.

Lew, H.; Adler, A.; Edinger, W. 1991. Moniliformin and the European maize borer (Ostrinia nubialis). Mycotoxin Research. 7A:71-76.

Lew, H.; Chelkowski, J.; Pronczuk, P.; Edinger, W. 1996. Occurrence of the mycotoxin moniliformin in maize (Zea mays L.) ears infected by Fusarium subglutinans (Wollenw \& Reinking) Nelson et al. Food Addit. Contam. $13: 321-324$.

Logrieco, A.; Moretti, A.;Ritieni, A.; Bottalico, A.; Corda, P. 1995. Occurrence and toxigenicity of Fusarium proliferatum from preharvest maize ear rot, and associated mycotoxins, in Italy. Plant Dis. 79:727-731.

Magg, T.; Bohn, M.; Klein, D.; Merditaj, V.; Melchinger, A. E. 2003. Concentration of moniliformin produced by Fusarium species in grains of transgenic Bt maize hybrids compared to their isogenic counterparts and commercial varieties under European maize borer pressure. Plant Breeding. $122: 322-327$

Miller, J. D.; Savard, M. E.; Schaafsma, K. A.; Seifert, L. M.; Reid, L. M. 1995. Mycotoxin production by Fusarium moniliforme and Fusarium proliferatum from Ontario and occurrence of fumonisin in the 1993 maize crop. Can. J. Plant Pathol. 17:233-239.

Morrison, E.; Kosiak, A.; Ritieni, A.; Aastveit, A. H.; Uhlig, S.; Bernhoft, A. 2002. Mycotoxin production by Fusarium avenaceum strains isolated from 
Norwegian grain and cytotoxicity of rice culture extracts kidney epithelial cells. J. Agric. Food Chem. 50:3070-3075.

Munimbazi, C.; Bullerman, L. B. 1998. High-performance liquid chromatographic method for the determination of moniliformin in maize. J. AOAC Int. 81:999-1004.

Papst, C.; Utz, H. F.; Melchinger, A. E.; Eder, J.; Magg T., Klein, D.; Bohn, M. 2005. Mycotoxins produced by Fusarium spp. in Isogenic Bt vs. non-Bt maize hybrids under European maize borer pressure. Agron. J. 97:219-224.

Parich, A.; Schuch Boeira, L.; Perez Castro, S.; Krska, R. 2003. Determination of moniliformin using SAX columns clean-up and HPLC/DAD-detection. Mycotoxin Res. 19:203-206.

Rabie C. J.; Marasas W. F. O.; Thiel P. G.; Lubben A.; Vleggaar R. 1982. Moniliformin production and toxicity of different Fusarium species from Southern Africa. Appl. Environ. Microbiol. 43:517-521.

Sanhueza C. E. P., Degrossi M. C. 2004. Moniliformin, a Fusarium mycotoxin. Revista Mexicana de Micologia. 19:103-112.

Scott, P. M.; Abbas, H. K.; Mirocha, C. J.; Lawrence, G. A.; Weber, D. 1987. Formation of moniliformin by Fusarium sporotrichioides and Fusarium culmorum. Appl. Environ. Microbiol. 53:196-197.

Sewram, V.; Niuwoudt, T. W.; Marasas, W. F. O.; Shephard, G. S.; Ritieni, A. 1999. Determination of the mycotoxin moniliformin in cultures of Fusarium subglutinans and in naturally contaminated maize by high- 
performance liquid chromatography-atmospheric pressure chemical ionization mass spectrometry. J. Chromatogr., A. 848:185-191.

418

Sharman, M.; Gilbert, J.; Chelkowski, J. 1991. A survey of the occurrence of the mycotoxin moniliformin in cereal samples from sources worldwide. Food Addit. Contam. 8:459-466.

Shepherd, M. J.; Gilbert, J. 1986. Method for the analysis in maize of the Fusarium mycotoxin moniliformin employing ion-pairing extraction and highperformance liquid chromatography. J. Chromatogr. 358:415-422.

Sørensen, J. L.; Nielsen, K. F.; Thrane, U. 2007. Analysis of moniliformin in maize plants using hydrophilic interaction chromatography. J. Agric. Food Chem. 55:9764-9768.

Springer, J. P.; Clardy, J.; Cole, R. J.; Kirksey, J. W.; Hill, R. K.; Carlson, R. M.; Isidor J. L. 1974. Structure and synthesis of moniliformin, a novel cyclobutane microbial toxin. J. Am. Chem. Soc. 96:2267-2268.

Steyn, M.; Thiel, P. G.; Van Shalkwyk, G. C. 1978. Isolation and purification of moniliformin. J. Assoc. Offic. Anal. Chem. 61:578-580.

Tang, L.; Kebarle, P. 1993. Dependence of ion intensity in electrospray mass spectrometry on the concentration of the analytes in the electrosprayed solution. Anal. Chem. 65:3654-3668.

Thalman, A.; Matzenauer, S.; Gruber-Schley, S. 1985. Untersuchungen über das Vorkommen von Fusarientoxinen in Getreide. Berichte über Landwirtschaft. 63:257-272. 
Thiel, P. G.; Meyer C. J.; Marasas W. F. O. 1982. Natural occurrence of moniliformin together with deoxynivalenol and zearalenone in Transkeian maize. J. Agric. Food Chem. 30-308-317.

Uhlig, S.; Torp, M.; Jarp, J.; Parich, A.; Gutleb, A. C.; Krska, R. 2004. Moniliformin in Norwegian grain. Food Addit. Contam. 21(6):598-606.

Vesonder, R. F.; Labeda, D. P.; Peterson, R. E. 1992. Phytotoxic activity of selected water-soluble metabolites of Fusarium against Lemma minor L. (Duckweed). Mycopathologia. 118:185-189.

Von Bargen, K. W.; Lohrey L.; Cramer, B.; Humpf H.-U. 2012. Analysis of the Fusarium mycotoxin moniliformin in cereals samples using ${ }^{13} \mathrm{C}_{2^{-}}$ moniliformin and High-Resolution Mass Spectrometry. J. Agric. Food Chem. 60:3586-3591.

Yu, S. R.; Liu, X. J.; Wang, Y. H. 1995. A survey of moniliformin contamination in rice and maize from Keshan disease endemic and non-KSD areas in China. Biomed. Environ. Sci. 8:330-334. 


\section{TABLES}

Table 1. Fusarium species most frequently associated with MON production in maize throughout the world.

\begin{tabular}{|c|c|c|}
\hline $\begin{array}{l}\text { Fusarium } \\
\text { species }\end{array}$ & $\begin{array}{c}\text { Other mycotoxins } \\
\text { produced }^{a}\end{array}$ & References \\
\hline F. proliferatum & FB, BEA, FP & $\begin{array}{l}\text { Logrieco et al. } 1995 \text { - Miller et al. } \\
1995\end{array}$ \\
\hline F. verticilliodes & FB, FUS & $\begin{array}{c}\text { Leslie et al. } 1996 \text { - Sanhueza et al. } \\
2004\end{array}$ \\
\hline F. subglutinans & BEA, FP & Kostecki et al. 1999 \\
\hline F. avenaceum & BEA, ENN, FUS & Morrison et al. 2002 \\
\hline $\begin{array}{c}\text { F. } \\
\text { chlamydosporum }\end{array}$ & - & CFP/EFSA/CONTAM/2008/01 \\
\hline F. oxysporum & BEA & CFP/EFSA/CONTAM/2008/01 \\
\hline F. tricinctum & BEA & CFP/EFSA/CONTAM/2008/01 \\
\hline
\end{tabular}


Table 2. Results of surveys on MON concentrations and distribution in naturally contaminated cereal commodities.

\begin{tabular}{|c|c|c|c|c|c|c|c|c|c|c|}
\hline Country & Year & Cereal & $\begin{array}{l}\text { Samples } \\
\left(\mathbf{n}^{\circ}\right)\end{array}$ & $\begin{array}{c}\mathrm{LOQ}^{b} \\
\left(\mu \mathrm{g} \mathrm{kg}^{-1}\right)\end{array}$ & $\begin{array}{c}n> \\
\text { LOQ }\end{array}$ & $\underset{\left(\mu g \mathrm{~kg}^{-1}\right)}{\operatorname{Min}}$ & $\underset{\left(\mu g \mathrm{~kg}^{-1}\right)}{\operatorname{Max}}$ & $\begin{array}{l}\text { Sampling } \\
\text { procedure }\end{array}$ & Clean-up & References \\
\hline Germany & $\mathrm{na}^{a}$ & Maize & 58 & na & 25 & na & $>650$ & na & na & $\begin{array}{c}\text { Talman et } \\
\text { al. } 1985\end{array}$ \\
\hline Worldwide & $\begin{array}{c}1985 \\
- \\
1989\end{array}$ & Maize & 64 & $50^{c}$ & 27 & $<50$ & 3160 & $\begin{array}{c}\text { Field samples } \\
\text { of maize from } \\
10 \\
\text { different } \\
\text { countries } \\
\end{array}$ & $\begin{array}{c}\text { SAX } \\
\text { columns }^{d}\end{array}$ & $\begin{array}{c}\text { Sharman et } \\
\text { al. } 1991\end{array}$ \\
\hline Austria & $\begin{array}{c}1991 \\
- \\
1992 \\
\end{array}$ & Wheat & 48 & $10^{c}$ & 29 & $<10$ & 880 & $\begin{array}{c}\text { Wheat from } \\
\text { Austrian } \\
\text { fields } \\
\end{array}$ & na & $\begin{array}{l}\text { Adler et al. } \\
\quad 1995\end{array}$ \\
\hline China & na & Maize & 104 & na & 47 & 52 & 1116 & $\begin{array}{l}\text { Maize from } \\
\text { Chinese fields }\end{array}$ & na & $\begin{array}{c}\text { Yu et al. } \\
1995\end{array}$ \\
\hline Austria & na & Maize & na & 20 & na & 50 & 2000 & $\begin{array}{c}\text { Maize from } \\
\text { Austrian } \\
\text { fields }\end{array}$ & $\begin{array}{c}\text { SAX } \\
\text { columns }\end{array}$ & $\begin{array}{c}\text { Filek and } \\
\text { Lindner } \\
1996 \\
\end{array}$ \\
\hline $\begin{array}{l}\text { South } \\
\text { Africa }\end{array}$ & 1997 & Maize & 4 & $5^{c}$ & 2 & $<5$ & 17 & $\begin{array}{c}\text { Maize } \\
\text { samples from } \\
\text { Transkei } \\
\end{array}$ & $\begin{array}{l}\text { RP-C18 } \\
\text { columns }\end{array}$ & $\begin{array}{c}\text { Sewram et } \\
\text { al. } 1999\end{array}$ \\
\hline
\end{tabular}




\begin{tabular}{|c|c|c|c|c|c|c|c|c|c|c|}
\hline USA & 1998 & Maize & 100 & $25^{c}$ & 83 & $<25$ & 774 & $\begin{array}{c}\text { Food-grade } \\
\text { commercial } \\
\text { maize } \\
\text { samples }\end{array}$ & na & $\begin{array}{l}\text { Gutema et } \\
\text { al. } 2000\end{array}$ \\
\hline Poland & na & Wheat & 10 & na & 4 & na & 200 & $\begin{array}{c}\text { Wheat from } \\
10 \text { private } \\
\text { farms }\end{array}$ & $\begin{array}{c}\text { Columns } \\
\text { containing } \\
\text { Florisil }^{\circledR} \\
\end{array}$ & $\begin{array}{l}\text { Krysinska- } \\
\text { Traczyk et } \\
\text { al. } 2001\end{array}$ \\
\hline Austria & na & Maize & na & $39^{c}$ & na & 160 & 1030 & $\begin{array}{l}\text { Maize from } \\
\text { Austrian } \\
\text { fields }\end{array}$ & $\begin{array}{l}\text { SAX } \\
\text { columns }\end{array}$ & $\begin{array}{l}\text { Parich et } \\
\text { al. } 2003\end{array}$ \\
\hline \multirow{3}{*}{ Finland } & \multirow{3}{*}{$\begin{array}{c}2001 \\
- \\
2002\end{array}$} & Barley & 22 & 20 & 22 & $<20$ & 750 & \multirow{3}{*}{$\begin{array}{c}\text { Cereals from } \\
\text { Southern and } \\
\text { Central } \\
\text { Finland fields }\end{array}$} & \multirow{3}{*}{ na } & \multirow{3}{*}{$\begin{array}{l}\text { Jestoi et al. } \\
\quad 2004\end{array}$} \\
\hline & & Wheat & 14 & 20 & 10 & $<20$ & 810 & & & \\
\hline & & Oats & 1 & 20 & 1 & - & 84 & & & \\
\hline \multirow{3}{*}{ Norway } & \multirow{3}{*}{$\begin{array}{c}2000 \\
- \\
2001\end{array}$} & Barley & 75 & 130 & 53 & $<130$ & 380 & \multirow{3}{*}{$\begin{array}{l}\text { Cereals from } \\
\text { Norwegian } \\
\text { fields }\end{array}$} & \multirow{3}{*}{$\begin{array}{l}\text { SAX } \\
\text { columns }\end{array}$} & \multirow{3}{*}{$\begin{array}{l}\text { Uhlig et al. } \\
\quad 2004\end{array}$} \\
\hline & & Wheat & 83 & 130 & 76 & $<130$ & 950 & & & \\
\hline & & Oats & 73 & 130 & 38 & $<130$ & 210 & & & \\
\hline Denmark & na & Maize & 28 & 12 & 0 & 1 & $<12$ & $\begin{array}{l}\text { Whole maize } \\
\text { plants }\end{array}$ & $\begin{array}{c}\text { SAX } \\
\text { columns }\end{array}$ & $\begin{array}{l}\text { Sørensen et } \\
\text { al. } 2007\end{array}$ \\
\hline
\end{tabular}

${ }^{a}$ Not available; ${ }^{b}$ LOQ $=$ Limit of Quantification; ${ }^{c}$ LOD $=$ Limit of Detection; ${ }^{d} \mathrm{SAX}=$ Strong anion exchange $;{ }^{e} \mathrm{RP}-\mathrm{C} 18=$ reversed-phase $(\mathrm{C} 18)$. 
Table 3. Recovery rate of the analytical method at four MON concentration levels.

\begin{tabular}{ccc}
\hline $\begin{array}{c}\text { MON Concentration } \\
\left.\boldsymbol{a}^{\boldsymbol{}} \boldsymbol{\mu g ~ k g}^{-\mathbf{1}}\right)\end{array}$ & $\begin{array}{c}\text { Recovery }^{\boldsymbol{b}} \\
\mathbf{( \% )}\end{array}$ & RSD $^{c}$ \\
\hline 3720 & 76 & 6 \\
372 & 76 & 8 \\
37.2 & 82 & 14 \\
3.72 & 91 & 9 \\
\hline
\end{tabular}

${ }^{a}$ Spiked MON levels $\left(\mu \mathrm{kg}^{-1}\right) ;{ }^{b}$ Mean recovery (\%) obtained from three replicas for each MON concentration level in three different days; ${ }^{c} \mathrm{RSD}=$ Relative Standard Deviation. 
Table. 4. Total rainfall, rainy days, relative humidity and growing degree days (GDD 10s) from June to October 2008-2011 in a representative site of the investigated maize growing area .

\begin{tabular}{|c|c|c|c|c|}
\hline Year & Month & $\begin{array}{c}\text { Rainfall } \\
\text { (mm) }\end{array}$ & $\begin{array}{c}\text { Rainy days } \\
\left(n^{\circ}\right)\end{array}$ & $\begin{array}{c}\text { GDD 10s }{ }^{a} \\
\left({ }^{\circ} \mathrm{C} \mathrm{d}^{-1}\right)\end{array}$ \\
\hline \multirow[t]{7}{*}{2008} & May & 121 & 16 & 204 \\
\hline & June & 95 & 17 & 304 \\
\hline & July & 63 & 8 & 382 \\
\hline & August & 52 & 6 & 372 \\
\hline & September & 57 & 8 & 228 \\
\hline & October & 30 & 5 & 151 \\
\hline & May-October & 418 & 60 & 1641 \\
\hline \multirow[t]{7}{*}{2009} & May & 30 & 10 & 292 \\
\hline & June & 26 & 7 & 341 \\
\hline & July & 121 & 8 & 391 \\
\hline & August & 56 & 11 & 404 \\
\hline & September & 62 & 8 & 273 \\
\hline & October & 54 & 6 & 163 \\
\hline & May-October & 349 & 50 & 1864 \\
\hline \multirow[t]{7}{*}{2010} & May & 117 & 12 & 214 \\
\hline & June & 192 & 11 & 332 \\
\hline & July & 37 & 8 & 420 \\
\hline & August & 116 & 11 & 354 \\
\hline & September & 51 & 12 & 240 \\
\hline & October & 105 & 9 & 120 \\
\hline & May-October & 618 & 63 & 1680 \\
\hline \multirow[t]{7}{*}{2011} & May & 42 & 7 & 286 \\
\hline & June & 104 & 13 & 335 \\
\hline & July & 59 & 7 & 364 \\
\hline & August & 9 & 2 & 431 \\
\hline & September & 24 & 3 & 346 \\
\hline & October & 19 & 1 & 111 \\
\hline & May-October & 257 & 33 & 1873 \\
\hline
\end{tabular}

${ }^{a}$ Accumulated growing degree days for each month using a $10^{\circ} \mathrm{C}$ base.

Data refer to the Carmagnola site ( $44^{\circ} 50^{\prime} \mathrm{N}, 7^{\circ} 40^{\prime} \mathrm{E}$; altitude $245 \mathrm{~m}$ ). 
Table 5. MON Concentrations in maize samples from North-West Italy over a four-year period (2008-2011).

\begin{tabular}{|c|c|c|c|c|}
\hline Year & $\begin{array}{c}\text { Samples }^{a, b} \\
\left(\mathrm{n}^{\circ}\right)\end{array}$ & $\begin{array}{c}\text { Mean MON } \\
\text { Concentration }^{c} \\
\left(\mu \mathrm{g} \mathrm{kg}^{-1}\right)\end{array}$ & $\begin{array}{c}\text { MON } \\
\text { Concentration } \\
\text { Range }\left(\mu \mathrm{g} \mathrm{kg}^{-1}\right)\end{array}$ & $\begin{array}{c}\text { Positives }^{e} \\
(\%)\end{array}$ \\
\hline 2008 & 16 & $1127 \pm 784$ & $33-2606$ & 100 \\
\hline 2009 & 16 & $106 \pm 135$ & $<\mathrm{LOD}^{d}-527$ & 81 \\
\hline 2010 & 40 & $262 \pm 243$ & $<$ LOD - 920 & 98 \\
\hline 2011 & 36 & $89 \pm 99$ & $<$ LOD - 409 & 92 \\
\hline
\end{tabular}

${ }^{a} \mathrm{~N}^{\circ}$ Samples $=$ Number of samples analyzed each year; ${ }^{b}$ Naturally contaminated maize samples collected in fields in North-West Italy; ${ }^{c}$ Concentrations not corrected for recovery; ${ }^{d}$ Limit of detection $(\mathrm{LOD})=1 \mu \mathrm{g} \mathrm{kg}^{-1} ;{ }^{e}$ Positive samples $=$ samples with MON concentration $\geq \mathrm{LOQ}$. 
Table 6. Mean data of ECB incidence and severity of ears collected in each sampling year.

\begin{tabular}{cccc}
\hline Year & $\begin{array}{c}\text { Samples } \\
\left(\mathbf{n}^{\circ}\right)\end{array}$ & $\begin{array}{c}\text { ECB incidence }^{a} \\
(\mathbf{\%})\end{array}$ & $\begin{array}{c}\text { ECB severity }^{b} \\
(\%)\end{array}$ \\
\hline 2008 & 16 & $99 \pm 2$ & $25 \pm 4$ \\
2009 & 16 & $68 \pm 19$ & $8 \pm 4$ \\
2010 & 40 & $78 \pm 16$ & $13 \pm 6$ \\
2011 & 36 & $40 \pm 13$ & $6 \pm 2$ \\
\hline
\end{tabular}

${ }^{a}$ ECB incidence was calculated as the percentage of ears with ECB damage, considering 100 ears per sample; ${ }^{b}$ ECB severity was calculated as the percentage of kernels per ear with ECB damage, considering 100 ears per sample. 


\section{FIGURES}

3

4

5

6

7

8

9

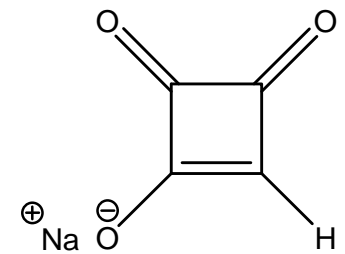

sodium 3,4-dioxocyclobut-1-enolate

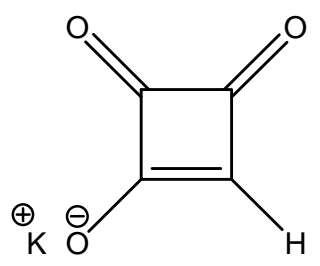

potassium 3,4-dioxocyclobut-1-enolate

10

11 Figure 1. Sodium and potassium salt structures of of 1-hydroxycyclobut-1-ene-3,412 dione $(\mathrm{MON})$.

13 


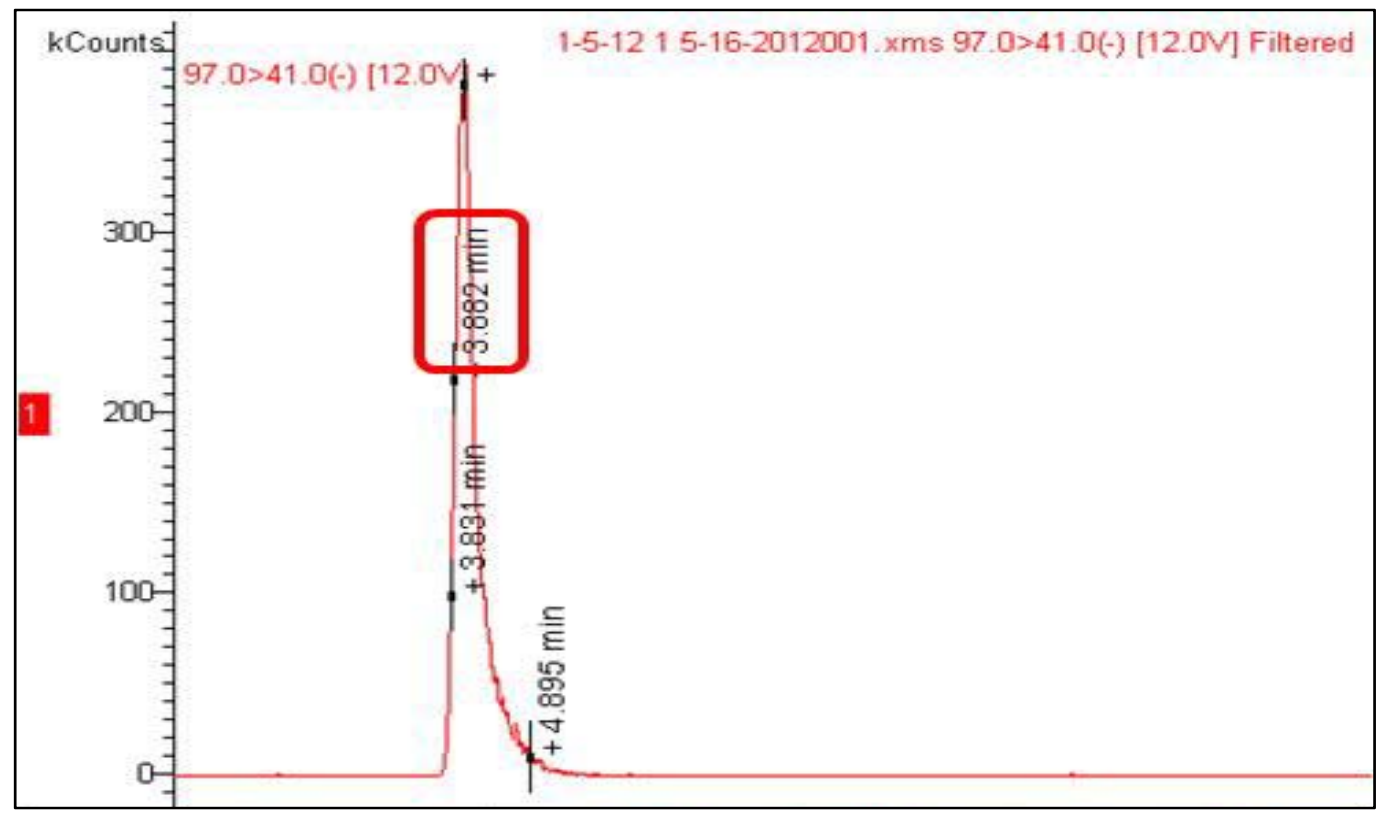

Figure 2. $\mathrm{LC}-\mathrm{MS} / \mathrm{MS}$ chromatogram of a maize sample $\left(\mathrm{t}_{\mathrm{R}} \mathrm{MON}=3.9 \mathrm{~min}\right)$.

19

20

21

22

23

24

25

26

27

28

29

30

31

32

33

34

35

36

37 


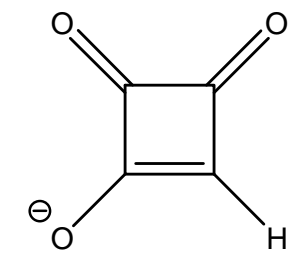

\section{3,4-dioxocyclobut-1-enolate}

$$
\mathrm{C}_{4} \mathrm{HO}_{3}^{-}
$$

Exact Mass: 97

Mol. Wt.: 97

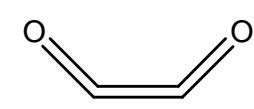

ethene-1,2-dione

$$
\mathrm{C}_{2} \mathrm{O}_{2}
$$

Exact Mass: 56

Mol. Wt.: 56

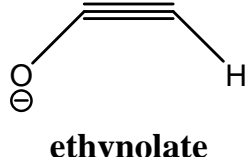

$\mathrm{C}_{2} \mathrm{HO}^{-}$

Exact Mass: 41

Mol. Wt.: 41

40

41 Figure 3. Presumed MON fragmentation pathway.

42

43 